\title{
PENGARUH KOMPENSASI, LINGKUNGAN KERJA, DAN MOTIVASI KERJA TERHADAP KINERJA PEGAWAI DINAS PENDIDIKAN KABUPATEN KERINCI
}

\author{
Riza Noverhadi Putra, SE ${ }^{1}$, Dr. H. Elfiswandi, SE.,MM.,Ak.,CA ${ }^{2}$ \\ ${ }^{1}$ Fakultas Ekonomi dan Bisnis Universitas Putra Indonesia "YPTK" Padang \\ e-mail : zhaputra2010@gmail.com \\ ${ }^{2}$ Fakultas Ekonomi dan Bisnis Universitas Putra Indonesia "YPTK" Padang \\ e-mail : elfiswandi@upiyptk.ac.id
}

\begin{abstract}
This study aims to determine how much influence the compensation, work motivation work environment has on employee performance in the Kerinci district education office. The analytical method used is regression analysis and correlation analysis. The results of the analysis show that the compensation, work environment and work motivation variables have a significant positive effect on employee performance variables, together. The amount of Adjusted $R$ Square is 0.682 . This means that $68.2 \%$ of the variation in employee performance can be explained by the three independent variables of compensation, work environment and work motivation. While the remaining $31.8 \%$ is explained by other variables outside this study such as job satisfaction, work performance and others.

Keyword: Compensation, Work Environment, and Work Motivation
\end{abstract}

\begin{abstract}
ABSTRAK
Penelitian ini bertujuan untuk mengetahui seberapa besar pengaruh kompensasi, lingkungan kerja motivasi kerja terhadap kinerja pegawai pada dinas pendidikan kabupaten Kerinci. Metode analisis yang digunakan adalah analisis regresi dan analisis korelasi. Hasil analisis menunjukkan bahwa antara variabel kompensasi, lingkungan kerja dan motivasi kerja mempunyai pengaruh yang positif signifikan terhadap variabel kinerja pegawai, secara bersama. Besarnya Adjusted $R$ Square adalah 0,682. Hal ini berarti bahwa $68,2 \%$ variasi kinerja pegawai dapat dijelaskan oleh ketiga variabel bebas kompensasi, lingkungan kerja dan motivasi kerja. Sedangkan sisanya 31,8\% dijelaskan oleh variabel-variabel lain di luar penelitian ini seperti kepuasan kerja, prestasi kerja dan lain-lain.
\end{abstract}

Kata Kunci: Kompensasi, Lingkungan Kerja dan Motivasi Kerja

(C) 2020 INFEB 


\section{PENDAHULUAN}

Sumber daya manusia adalah salah satu faktor yang sangat penting bahkan tidak dapat dilepaskan dari sebuah organisasi, baik institusi maupun perusahaan. Sumber daya manusia juga merupakan kunci yang menentukan perkembangan suatu organisasi, sumber daya manusia merupakan manusia yang diperkerjakan di sebuah organisasi sebagai pengerak, pemikir dan perencanaan untuk mencapai tujuan organisasi tersebut.

Untuk meningkatkan mutu sumber daya manusia salah satunya yaitu melalui Pendidikan. Menuju era globalisasi yang penuh dengan tantangan, jadi disadari bahwa pendidikan merupakan suatu yang sangat fundenmental bagi setiap individu karena pendidikan sangat penting untuk menjamin perkembagan dan kelangsungan hidup bangsa.

Dalam mengembangkan pendidikan di butuhkan tenaga sumber daya manusia dan bagaimana sumber daya manusia tersebut dikelola. Pengelolaan sumber daya manusia dimulai dari proses rekruitmen, training sampai proses maintainnya. Pengelolaan sumber daya manusia yang matang dimulai dari awal karena nantinya akan sangat menentukan kelangsungan organisasi, terutama kelangsungan organisasi pada Dinas Pendidikan Kabupaten Kerinci.

Isu strategis merupakan bagian penting dan sangat menentukan dalam proses penyusunan rencana kerja dalam rangka melengkapi tahapan- tahapan yang telah dilakukan sebelumnya. Identifikasi analisis terhadap kinerja pelayanan Dinas Pendidikan, permasalahan dan hambatan dalam penyelengaraan tugas dan fungsi, capaian terhadap visi dan misi kepala daerah, capaian program nasional, tantangan dan peluang maka ditentukan isu strategis Dinas Pendidikan yaitu:

a. Masih kurangnya SDM baik secara kualitas maupun kuantitas;

b. Belum terlihatnya satu kesatuan antar bidang dalam Dinas Pendidikan;

c. Ruangan Kantor yang kurang memadai;

d. Adanya Pejabat yang masih belum mengerti dan menjalankan tupoksi;

e. Pemanfaatan teknologi yang belum maksimal;

f. Jarak sekolah dengan dinas pendidikan yang jauh.

Untuk kelangsungan organisasi Dinas Pendidikan di Kabupaten Kerinci, kinerja pegawai sangat penting. Sidanti, (2015:12) mengatakan bahwa pengertian kinerja adalah kesediaan seseorang atau kelompok orang untuk melakukan sesuatu kegiatan dan menyempurnaannya sesuai dengan tanggung jawab dengan hasil seperti yang diharapkan.

Kinerja pegawai dapat dipengaruhi oleh banyak faktor, salah satu di antaranya kompensasi. Menurut Hasibuan, (2013:118), kompensasi adalah semua pendapatan yang berbentuk uang, barang langsung atau tidak langsung yang diterima karyawan sebagai imbalan atas jasa yang diberikan kepada perusahaan.

Lingkungan kerja adalah lingkungan di mana pegawai melakukan pekerjaannya sehari-hari. Lingkungan kerja yang kondusif memberikan rasa aman dan memungkinkan para pegawai untuk dapat bekerja optimal. Lingkungan kerja dapat mempengaruhi emosi pegawai. Jika pegawai menyenangi lingkungan kerja di mana dia bekerja, maka pegawai tersebut akan betah di tempat kerjanya untuk melakukan aktivitas sehingga waktu kerja dipergunakan secara efektif dan optimal, prestasi kerja pegawai juga tinggi. Lingkungan kerja tersebut mencakup hubungan kerja yang terbentuk antara sesama pegawai dan hubungan kerja antara bawahan dan atasan serta lingkungan fisik tempat pegawai bekerja. 
Motivasi merupakan suatu dorongan untuk mau mengikuti suatu aktivitas. Asthu (2016: 145) mendefinisikan motivasi sebagai proses yang menjelaskan intensitas, arah dan ketekunan seorang individu untuk mencapai tujuannya. Lebih lengkap lagi dia menjelaskan tiga eleman utama dalam definisi motivasi adalah intensitas, arah, dan ketekunan. Intensitas berhubungan seberapa giat seseorang berusaha. Ini merupakan elemen yang paling banyak mendapatkan perhatian ketika berbicara tentang motivasi. Namun, intensitas yang tinggi sepertinya tidak akan menghasilkan prestasi kerja yang memuaskan kecuali upaya tersebut dikaitkan dengan arah yang menguntungkan organisasi.

\section{METODOLOGI PENELITIAN}

\subsection{Objek Penelitian}

Penelitian ini dilakukan di Dinas Pendidikan Kabupaten Kerinci. Waktu penelitian ini dilaksanakan pada bulan Desember 2019, namun beberapa persiapan telah dilakukan sebelumnya. Hal ini didasarkan berbagai faktor untuk memperlancar pengumpulan data dalam penelitian, seperti kemudahan pengambalian data dan menghemat waktu serta tenaga yang digunakan.

\subsection{Variabel Operasional}

Pada penelitian ini penulis menggunakan dua variabel yaitu:

- Variabel independen (bebas)

Variabel bebas adalah merupakan variabel yang mempengaruhi atau yang menjadi sebab perubahannya atau timbulnya variabel dependen atau terikat. Dalam penelitian ini yang menjadi variabel bebas (independent variable) adalah Kompensasi $\left(\mathrm{X}_{1}\right)$, Lingkungan Kerja $\left(\mathrm{X}_{2}\right)$, Motivasi Kerja $\left(\mathrm{X}_{3}\right)$.

- Variabel dependen (terikat)

Variabel terikat merupakan variabel yang dipengaruhi atau yang menjadi akibat, karena adanya variabel bebas. Dalam penelitian ini yang menjadi variabel terikat (dependent variable) adalah Kinerja Pegawai (Y).

\subsection{Populasi dan Sampel}

Populasi adalah wilayah generalisasi yang terdiri atas objek/subyek yang mempunyai kualitas dan karakteristik tertentu yang ditetapkan oleh peneliti untuk dipelajari dan kemudin ditarik kesimpulannya (Uhing, 2017) dalam penelitian ini yang menjadi populasi adalah seluruh pegawai pada Dinas Pendidikan Kabupaten Kerinci yaitu 95 orang.

Besarnya jumlah sampel yang mendekati populasi, maka peluang kesalahan generalisasi semakin kecil dan sebaliknya makin kecil jumlah sampel (menjahui populasi) maka semakin besar kesalahan generalisasi. Berdasarkan pendapat yang diuraikan di atas, maka penelitian ini pupulasi ditetapkan sebagai sampel dengan jumlah pegawai 95 orang atau sampel jenuh. Uji coba kuesioner dilakukan kepada 30 orang responden dari populasi di atas dalam pelaksanaan penelitian yaitu sebanyak 95 orang responden.

\subsection{Analisis Regresi Linier Berganda}

Analisis regresi linier berganda berguna untuk menganalisis seberapa besar pengaruh antara beberapa variabel independent dengan satu variabel dependent yang ditampilkan dalam bentuk persamaan regresi. Variabel independent dalam penelitian ini di lambangkan dengan $\left(\mathrm{X}_{1}\right),\left(\mathrm{X}_{2}\right),\left(\mathrm{X}_{3}\right)$ sedangkan variabel dependent di lambangkan dengan (Y). Teknik analisis data yang digunakan untuk memprediksi nilai variabel terikat yaitu Kinerja Pegawai $(\mathrm{Y})$ dengan variabel bebas yaitu Kompensasi $\left(\mathrm{X}_{1}\right)$, Lingkungan Kerja $\left(\mathrm{X}_{2}\right)$, Motivasi Kerja 
$\left(\mathrm{X}_{3}\right)$ Bentuk umum persamaan regresi berganda dapat digunakan dengan rumus, Idris (2011:52) sebagai berikut :

$$
Y=a+b_{1} X_{1}+b_{2} X_{2}+b_{3} X_{3}+e
$$

Keterangan :

$$
\begin{aligned}
& \mathrm{Y}=\text { Kinerja pegawai } \\
& \mathrm{a}=\text { Konstanta } \\
& \mathrm{b}=\text { Koefisien regresi } \\
& \mathrm{X}_{1}=\text { Kompensasi } \\
& \mathrm{X}_{2}=\text { Lingkungan kerja } \\
& \mathrm{X}_{3}=\text { Motivasi kerja } \\
& \mathrm{e}=\text { error }
\end{aligned}
$$

\section{Uji Parsial (Uji-t)}

Uji t yaitu suatu pengujian untuk mengetahui signifikansi pengaruh variabel bebas secara parsial atau individual terhadap variabel terikat Sugiyono (2013 : 194).

\section{Uji Simultan (Uji-F)}

Uji F yaitu suatu pengujian untuk mengetahui apakah variabel bebas secara bersamasama berpengaruh signifikan terhadap variabel terikat Sugiyono (2014:192).

\section{Uji Koefisien Determinasi (R-Square/ $\left.\mathbf{R}^{\mathbf{2}}\right)$}

Koefisien determinasi $\left(\mathrm{R}^{2}\right)$ digunakan untuk mengukur seberapa jauh kemampuan model dalam menerangkan variasi variabel dependen. Nilai koefisien determinasi adalah antara nol dan satu. Nilai $\mathrm{R}^{2}$ yang kecil berarti kemampuan variabel independen dalam menjelaskan variabel dependen yang terbatas.

\section{III.HASIL DAN PEMBAHASAN}

Berdasarkan sampel yang telah ditentukan diatas maka diperoleh responden sebanyak 95 orang. Dimana 95 responden tersebut peneliti ambil dari keseluruhan populasi yang ada pada Dinas Pendidikan Kabupaten Kerinci. Data yang disebarkan sebanyak 95 kuesioner dan berhasil dikumpulkan kembali kemudian diolah semuanya.

\section{Uji Normalitas}

Sarjono (2011:53) menyatakan, uji normalitas bertujuan untuk mengetahui normal atau tidaknya suatu distribusi data. Pada dasarnya, uji normalitas adalah membandingkan antara data yang kita miliki dan data berdistribusi normal yang memiliki mean dan standar deviasi yang sama dengan data kita. data yang diuji lebih besar daripada 50 (respondennya lebih dari 50 orang) menggunakan angka signifikansi uji kolmogorov-Smirnov. Jika data yang diuji lebih kecil dari pada 50, peneliti menggunakan sig Shapiro Wilk. Tingkat signifikan > 0,05 menunjukkan data berdistribusi normal.

\section{Tabel 4.1 Uji Normalitas}

\begin{tabular}{llr}
\hline & & \multicolumn{2}{r}{ Unstandardized Residual } \\
\hline $\mathrm{N}$ & & 95 \\
Normal Parameters ${ }^{\mathrm{a}, \mathrm{b}}$ & Mean &, 0000000 \\
& Std. Deviation & 2,62563956 \\
Most Extreme Differences & Absolute &, 105
\end{tabular}




\begin{tabular}{lrr} 
& Positive &, 105 \\
& Negative &,- 096 \\
Test Statistic & & 1,020 \\
Asymp. Sig. (2-tailed) &, 249 \\
\hline \multicolumn{2}{c}{ Sumber : Data diolah peneliti, 2020 }
\end{tabular}

\section{Uji Multikolinearitas}

Multikorelasi adalah korelasi yang sangat tinggi atau sangat rendah yang terjadi pada hubungan di antara variabel bebas. Multikorelasi dapat dilihat dari nilai VlF (variance inflating factor). Jika nilai VIF < 10 maka tidak terjadi gejala multikolinearitas, jika nilai VIF $>10$ maka terjadi gejala multikolinearitas (Sarjono, 2011:74).

\section{.Tabel 4.2 Hasil Uji Multikolinearitas}

\begin{tabular}{|c|c|c|}
\hline \multirow[b]{2}{*}{ Model } & \multicolumn{2}{|c|}{ Collinearity Statistics } \\
\hline & Tolerance & VIF \\
\hline 1 (Constant) & & \\
\hline Tot. $X_{1}$ & ,792 & 1,262 \\
\hline Tot. $X_{2}$ & ,866 & 1,155 \\
\hline Tot. $X_{3}$ & ,705 & 1,419 \\
\hline
\end{tabular}

Dari tabel di atas dapat diketahui nilai VIF 1,262 untuk $\mathrm{X}_{1}$ (kompensasi), nilai VIF 1,155 untuk $\mathrm{X}_{2}$ (lingkungan kerja), dan nilai VIF 1,419 untuk $\mathrm{X}_{3}$ (motivasi kerja). Karena keseluruhan nilai lebih rendah dari 10 sehingga dapat disimpulkan tidak terjadi multikolinearitas, Dengan demikian semua variabel bebas yang diteliti dapat memenuhi syarat pemakaian model regresi berganda.

\section{Uji Heteroskedastisitas}

Hasil pengujian heteroskedastisitas untuk masing-masing variabel kepemimpinan, kompetensi, disiplin kerja dan kinerja pegawai dapat dilihat pada gambar di bawah ini :

\section{Gambar 4.3 Hasil Uji Heteroskedastisitas}

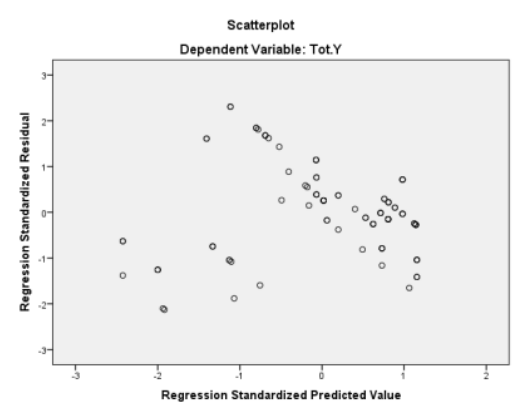

Sumber : Data diolah peneliti, 2020

Dari gambar diatas dapat dilihat bahwa tidak ada pola yang jelas. Hal tersebut dapat dilihat dari plot yang berpencar di atas dan di bawah angka 0 dan tidak membentuk pola tertentu. Dengan demikian dapat disimpulkan tidak terjadi heteroskedastisitas.

\section{Analisis Regresi Linier Berganda}


Analisis dalam penelitian ini adalah analisis regresi berganda. Analisis ini digunakan untuk mengetahui Pengaruh Kompensasi, Lingkungan Kerja, Motivasi Kerja terhadap Kinerja Pegawai pada Dinas Pendidikan Kabupaten Kerinci. Adapun bentuk regresinya adalah sebagai berikut:

Tabel 4.3 Hasil Regresi Linier Berganda

\begin{tabular}{lrrrr}
\hline \multicolumn{5}{c}{ Unstandardized Coefficients } \\
Model & \multicolumn{1}{c}{ B } & \multicolumn{1}{c}{ Std. Error } & \multicolumn{1}{c}{ t } & Sig. \\
\hline 1 (Constant) & 10,825 & 1,886 & 5,739 &, 000 \\
Tot. $X_{1}$ &, 344 &, 041 & 8,454 &, 000 \\
Tot.X &, 073 &, 032 & 2,280 &, 025 \\
Tot.X &, 213 &, 038 & 5,534 &, 000 \\
\hline
\end{tabular}

Sumber : Data diolah peneliti, 2020

Berdasarkan perhitungan diperoleh nilai koefisien regresi kompensasi $\left(\mathrm{X}_{1}\right)$ sebesar 0,344 , nilai koefisien regresi lingkungan kerja $\left(\mathrm{X}_{2}\right)$ sebesar 0,073 , nilai koefisien regresi motivasi kerja $\left(\mathrm{X}_{3}\right)$ sebesar 0,213 . Berdasarkan angka tersebut maka dapat disusun persamaan garis regresi sebagai berikut :

$$
Y=10,825+0,344 X_{1}+0,073 X_{2}+0,213 X_{3}+e
$$

\section{Uji Parsial (Uji-t)}

Uji statistik t digunakan untuk menunjukkan seberapa jauh pengaruh satu variabel independen terhadap variabel dependen dengan menganggap variabel independen lainnya konstan. Berdasarkan tabel 4.3 diatas maka dapat ditarik kesimpulan bahwa :

1. Pengaruh Kompensasi Terhadap Kinerja Pegawai

Dari tabel 4.3 terlihat t-hitung 8,454 dan t-tabel 1,661 dimana t-hitung lebih besar dari t-tabel $(8,454>1,986)$ atau tingkat signifikan lebih kecil dari alpha $(0,000<0,05)$ maka dapat diperoleh $\mathrm{H}_{0}$ ditolak $\mathrm{H}_{\mathrm{a}}$ diterima.

2. Pengaruh Lingkungan Kerja terhadap Kinerja Pegawai

Dari tabel 4.3 terlihat t-hitung 2,280 dan t-tabel 1,661 dimana t-hitung lebih besar dari t-tabel $(2,280>1,986)$ atau tingkat signifikan lebih kecil dari alpha $(0,025<0,05)$ maka dapat diperoleh $\mathrm{H}_{0}$ ditolak $\mathrm{H}_{\mathrm{a}}$ diterima.

3. Pengaruh Motivasi KerjaTerhadap Kinerja Pegawai

Dari tabel 4.3 terlihat t-hitung 5,534 dan t-tabel 1,986 dimana t-hitung lebih besar dari t-tabel $(5,534>1,986)$ atau tingkat signifikan lebih kecil dari alpha $(0,000<0,05)$ maka dapat diperoleh $\mathrm{H}_{0}$ ditolak $\mathrm{H}_{\mathrm{a}}$ diterima.

\section{Uji Simultan (Uji-F)}

Untuk mendapatkan bukti empiris ada atau tidaknya pengaruh nyata antara variabel yang terdiri dari kompensasi, lingkungan kerja dan motivasi kerja secara bersama-sama terhadap kinerja pegawai, maka dilakukan F-test. Berdasarkan hasil pengujian diperoleh ringkasan hasil seperti yang terlihat pada tabel di bawah ini : 
Tabel 4.4 Hasil Uji Simultan

\begin{tabular}{lrrrrr}
\hline Model & Sum of Squares & df & Mean Square & F & Sig. \\
\hline 1 Regression & 1456,871 & 3 & 485,624 & 68,194 &, $000^{\mathrm{b}}$ \\
Residual & 648,034 & 91 & 7,121 & & \\
Total & 2104,905 & 94 & & & \\
\hline
\end{tabular}

Sumber : Data diolah peneliti, 2020

Dari tabel 4.4 di atas, diketahui bahwa pengujian ini dilakukan dengan cara membandingkan nilai F-hitung dengan F-tabel karena nilai F-hitung lebih besar dari nilai Ftabel $(68,194>2,70)$. Nilai F 68,194 dengan tingkat signifikan 0,000 lebih kecil dari 5\%. Maka dapat disimpulkan bahwa $\mathrm{H}_{\mathrm{o}}$ ditolak dan $\mathrm{H}_{\mathrm{a}}$ diterima, yang berarti Kompensasi, Lingkungan Kerja dan Motivasi Kerja berpengaruh Signifikan terhadap Kinerja Pegawai.

\section{Uji Koefisien Determinasi (R-Square)}

Berdasarkan hasil dari data yang telah diproses dapat dilihat kontribusi variabel kepemimpinan, kompetensi dan disiplin kerja terhadap kinerja pegawai. Berdasarkan hasil pengujian diperoleh ringkasan hasil seperti yang terlihat pada tabel di bawah ini :

Tabel 4.5 Hasil Uji Koefisien Determinasi

\begin{tabular}{lrrrr}
\hline & & & \multicolumn{2}{c}{ Durbin-Watson } \\
Model & $\mathrm{R}$ & R Square & Adjusted R Square & \\
\hline 1 &, $832^{\mathrm{a}}$ &, 692 &, 682 & 2,66857 \\
\hline
\end{tabular}

Sumber : Data diolah peneliti, 2020

Dari tabel di atas diketahui kompensasi, lingkungan kerja dan motivasi kerja terhadap kinerja pegawai dengan nilai korelasi kuat terlihat dari nilai koefisien sebesar (R) 0,832 . Hasil adjusted $\mathrm{R}^{2}$ diperoleh nilai koefisien sebesar 0,682 atau $68,2 \%$. Artinya adalah kompensasi, lingkungan kerja dan motivasi kerja proporsinya secara simultan menjelaskan pengaruh terhadap kinerja pegawai sebesar $68,2 \%$, sedangkan sisanya sebesar $31,8 \%$, dijelaskan oleh variabel lain yang tidak digunakan dalam penelitian ini.

\section{Pembahasan}

1) Pengaruh Kompensasi terhadap Kinerja Pegawai

Dimna t-hitung 8,454 dan t-tabel 1,986 dimana t-hitung lebih besar dari t-tabel $(8,454>1,986)$ atau tingkat signifikan $(0,000<0,05)$. Hasil tersebut sesuai dengan dugaan peneliti terdahulu yang dilakukan oleh (Rustilah, 2018) dengan hasil yang menunjukan terdapat kompensasi berpengaruh signifikan terhadap kinerja pegawai.

2) Pengaruh Lingkungan Kerja terhadap Kinerja Pegawai

Dimana t-hitung 2,280 dan t-tabel 1,986 dimana t-hitung lebih besar dari t-tabel $(2,280>1,986)$ atau tingkat signifikan $(0,025<0,05)$. Hasil tersebut sesuai dengan dugaan peneliti terdahulu yang dilakukan oleh (Sidanti, 2015) dengan hasil yang menunjukan terdapat lingkungan kerja berpengaruh signifikan terhadap kinerja pegawai .

3) Pengaruh Motivasi Kerja terhadap Kinerja Pegawai

Dimana t-hitung 5,534 dan t-tabel 1,986 dimana t-hitung lebih besar dari t-tabel $(5,534>1,986)$ atau tingkat signifikan $(0,000<0,05)$. Hasil tersebut sesuai dengan dugaan peneliti terdahulu yang dilakukan oleh (Nurcahyani, 2016) dengan hasil menunjukan terdapat motivasi kerja berpengaruh terhadap kinerja pegawai .

4) Pengaruh Kompensasi, Lingkungan Kerja, Motivasi Kerja terhadap Kinerja Pegawai. 
Dimana F-hitung lebih besar dari F tabel $(68,194>2,70$. Nilai F 6,804 dengan tingkat signifikan 0,000 lebih kecil dari 5\%.

5) Sumbangan-sumbangan Kompensasi, Lingkungan Karja, Motivasi Kerja terhadap Kinerja Pegawai sebesar 0,692 atau 69,2\% sedangkan sisanya sebesar 30,8\% dipengaruhi oleh variabel lain.

\section{KESIMPULAN}

Hasil penelitian ini menunjukkan bahwa kompensasi berpengaruh dan signifikan terhadap kinerja pegawai, lingkungan kerja berpengaruh dan signifikan terhadap kinerja pegawai, motivasi kerja berpengaruh dan signifikan terhadap kinerja pegawai, kompensasi, lingkungan kerja dan motivasi kerja secara bersama-sama berpengaruh dan signifikan terhadap kinerja pegawai Dinas Pendidikan Kabupaten Kerinci.

\section{UCAPAN TERIMAKASIH}

Terima kasih kepada Universitas Putra Indonesia "YPTK" Padang yang telah memberikan kesempatan penulis untuk menyelesaiakan jurnal ini dan LPPM STIA Nusantara Sakti Sungai Penuh yang telah memberi kesempatan untuk publish jurnal di OJS Jurnal Administrasi Nusantara (JAN). Sertasemua pihak yang tidak bisa disebutkan satu persatu dalam jurnal ini.

\section{VI.DAFTAR RUJUKAN}

Arif, Yusuf Hamali. 2016. Pemahaman manajemen sumber daya manusia. Yogyakarta: CAPS

Asthu. 2016. Pengaruh kepuasan kerja, motivasi, dan komitmen organisasional terhadap kinerja perawat rumah sakit umum di kota Bandung.

Tesis Institut Pertanian Bogor

Aunurrahman. 2014. Belajar dan Pembelajaran. Cetakan Kesembilan. Bandung :

Alfabeta

Arianto, 2013. Pengaruh kedisiplina, lingkungan kerja dan budaya organisasi terhadap kinerja tenaga pegajar. Tesis Universitas Islam Nahdlatul Ulama Jepara, Indonesia

Bhutta, dkk.2019. Enhancing Performance And Commitment Through Leadership And Empowerment.International journal of Bank Markerting.ISSN 02652323

Dwi, dkk.2019.Pengaruh Penepatan Kerja Dan Kompensasi Terhadap Semagat Kerja Pegawai Dinas Kebudayaan Dan Pariwisata Provinsi Sumatra Utara.Tesis Universitas Medan Area.

Deswarta, dkk.2017.pengaruh kompetensi dan motivasi terhadap kepuasan kerja dan kinerja dosen fakultas tarbiyah dan keguruan UIN Sutan Syarif Kasim Riau. Jurnal Valuto ISSN:2502-1419. 
Dermawan,dkk.2012. pengaruh motivasi, lingkungan kerja,kompetensi, terhadap kepuasan kerja dan kinerja pegawai di lingkungan Kantor Dinas Pekerjaan Umum Provinsi Bali. Jurnal Manajemen

Edy Sutrisno, 2014. Manajemen Sumber Daya Manusia, Bandung: PT. Mulia Kencana Semesta

Faitullah. 2014. pengaruh kompetensi, motivasi dan kecerdasan emosi terhadap kinerja dosen di perguruan tinggi swasta Kompertis Wilayah ll (study kasus pada universitas Binadarma dan Universitas Tridinarti. Jurnal manajemen dan bisnis Sriwijaya (2014)

Fahmi, M.R (2018) Pengaruh Budaya Organisasi dan Komitmen Organisasi Terhadap Kinerja Karyawan. Jurnal Ekonomi dan Bisnis Universitas Muhammadiyah Sumatera Utara.

Goleman, Daniel 2015. Emotional Intelligence : Kecerdasan emosional mengapa EI lebih penting dari pada IQ, Jakarta: PT. Gramedia Pustaka Utama.

Hasibuan, S.P Melayu.2013.Manajemen Sumber Daya Manusia. Jakarta:PT Bumi Aksara Indrasari, Meithian. 2017. Kepuasan Kerja dan Kinerja Karyawan.Yogyakarta: Infomedia Idris, 2011.Aplikasi Model Analisis Data Kuantitatif dengan Program SPSS.Edisi

Revisi Ketiga. Padang Magister Manajemen.UNP

Khodijah, Nyayu. 2014. Psikologi Pendidikan. Jakarta :Rajawali Pers

Lupiyoadi, Rambat.2014. Manajemen Pemasaran Jasa. Jakarta: Salemba Empat

Mangkunegara, Prabu Anwar.2014.Evaluasi Kinerja SDM. Cetakan ketujuh.

Bandung: PT Refika Aditama

Martono, Nanang.2014.Metode penelitian kuatitatif.

Jakarta: Raja Grafindo Persada

Masngudi, Noor Salim.M. (2012). Metode Penelitian

Untuk Ekonomi Dan Bisnis, Jakarta, Rianda

Universitas Press

Sulistiyo Ningsih,.2017. Pengaruh motivasi kerja terhadap kinerja guru di Maal-Hikmah Wayhalim Kedaton Bandar Lampung. Jurnal Universitas Islam Negeri Raden Intan Lampung.

Nurcahyani, Adnyani.2016. Pengaruh Kompetensi Dan Motivasi Terhadap Kinerja Karyawan Dengan Kepuasan Kerja Sebagai Variabel Intervening.E-Jurnal Manajemen Unud,Vol 5, No. 1, ISSN: 2302-8912

Putra Adistyana Septian.2011.Pengaruh kompensasi dan kepuasan kerja karyawan PT.Borwita Citra Prima di Sidoarjo.Jurnal Manajemen Universitas Pembangunan Nasional Jawa Timur.

Palliam,dkk.2012. Nabling a motivated workforce: exploring the sources of motivation. Jurnal Managemen Decision, vol 52 ISSN-4937454

Rustilah.2018. Pengaruh Kepemimpinan dan Kompensasi terhadap Kepuasan

Kerja dan Kinerja Pegawai Tenaga Kontrak. Jurnal managemen ISSN-P: 413812580-

Robbins, P.Stephen dan Timothy A. Judge. 2012. Perilaku Organisasi. Jakarta Salemba Empat.

Robbins, SP dan Judge T.A. 2013. Perilaku Organisasi Manajemen. Jakarta: Salemba Empat 
Rahmawati, Fajar. 2016. Pengaruh motivasi dan kompensasi terhadap kinerja karyawan dengan kepuasan kerja sebagai variabel intervening (study empiris pada kantor DPPKAD Kabupaten Karanganyar).Tesis Universitas Muhammadiyah Surakarta.

Supardi.2014.Kinerja Guru.Jakarta: Raja Grafindo Persada.

Sari dkk, 2017.Pengaruh peran kepemimpinan kepala sekolah dan peranan komitmen sekolah terhadap kinerja guru SD di Kabupaten Lampung. Tesis Magister Manajemen Fakultas keguruan dan Ilmu Pendidikan Lampung

Sidanti, Heny.2015.Pengaruh Lingkungan Kerja, Disiplin Kerja dan Motivasi Kerja

Terhadap Kinerja Pegawai Negeri Sipil di Sekretariat DPRD Kabupaten Madiun.Jurnal JIBEKA, Vol 9.

Sangadji, Mamang dan Sopiah. 2013. Perilaku Konsumen. Yogyakarta: Andi

Singh,dkk.2018. Interplay of organizational justice psychological empowerment,

organization citizenhip behavarior, and job statisfaction in the context of circular economy. Jornal Manajemen Deicision vol.57 ISSUE:PP.937-952

Sugiyono.2013. Metode penelitian kuantitatif, kualitatif dan R\&D. Bandung: Alfabeta

Sulistyowati dkk.2017. Pengaruh kecerdasan emosional, disiplin kerja dan kualitas layanan terhadap kinerja pegawai negeri sipil pada kantor BPKAD Kota Kendari. Jurnal Universitas Halu Oleo.

Shankar.2016. Immigrant job satisfaction The Australia journal international of manpower, vol.37 issue:1 sp.99-144profesional drivers.

Saibokaithe.2012. The role of personality traits, work motivation and organizational safety climate in risky occupational perfomance of. Baltic Journal of Management.vol 7:pp.103-188.

Somia,dkk.2017. Behavioural competencies and organizational perfomance performing arts:an exploratory study. Latin American Jurnal of Management Academy, vol 30 issue, 2;pp 192-214

Sofiyan Rizal. (2018). Lingkungan Kerja Dan Kepuasan Kerja Berpengaruh Terhadap Kualitas Layanan.Journal of Management Universitas Galuh,ISSN-P2580-4138

Sutrisno, Edy. 2015. Manajemen Sumber Daya Manusia (Cetakan ke tujuh). Jakarta: Kencana Prenada Media Group.

Sugiyono.2014.Metode penelitian kuantitatif,kualitatif dan R\&D.Bandung:Alfabeta

Simamora, Henry.2012.Akuntansi Manajemen, Edisi Ketiga.Riau: Star Gate Publisher.

Sarjono, Haryadi., dan Julianita, Winda. (2011). SPSS vs LISREL: Sebuah Pengantar, Aplikasi untuk Riset. Jakarta. Penerbit Salemba empat,

Tjiptono, Fandy.2012.Service Management.Edisi Kedua.Yogyakarta:Andi

Uhing, F.M. (2017).Pengaruh Stres Kerja dan Kepuasan Kerja Terhadap Kinerja Karyawan Pada Kantor Pelayanan Kekayaan Negara dan Lelang Manado1,2,3 Fakultas Ekonomi dan Bisnis, Jurnal Manajemen Universitas Sam Ratulagi Manado

Umar, Husein.2014.Metode penelitian untuk skripsi dan tesis.Jakarta:Rajawali

Umar, Husein. 2014. Metode Penelitian untuk Skripsi dan Tesis Bisnis. Jakarta: PT. Raja GrafindoPersada

Viani, C.O. 2015. Pengaruh Kompensasi Terhadap Kinerja Karyawan.Jurnal Ekonomi \& Bisnis,Universitas Negeri WaliSongo 
Wibowo. 2017. Manajemen Kinerja. Edisi Kelima. Depok: PT. Raja Grafindo Persada.

Wibowo. 2013. Manajemen Kinerja. Jakarta:PT. Raja Grafindo Persada

Winardi. 2011.Kepemimpinan dalam Manajemen, Jakarta. PT. Rineka Cipta.

Wijaya. 2016. Analisis pengaruh kepuasan kerja terhadap komitmen efektif OCB pada karyawan di Restoran Surabaya.Jurnal Manajemen Perhotelan. 